\title{
Comparative Haematobiochemical Analysis between Haemorrhagic Enteritis affected Dogs with Normal Ones
}

\author{
S. P. Maharathi ${ }^{1}$, N. Dalai ${ }^{1 *}$, S. R. Mishra ${ }^{1}$, S. Mohapatra ${ }^{1}$, A. P. K. Mahapatra ${ }^{1}$, \\ A. K. Kundu ${ }^{1}$, I. Nath ${ }^{2}$, S. Dash ${ }^{3}$ and G. R. Jena ${ }^{4}$ \\ ${ }^{1}$ Department of Veterinary Physiology, ${ }^{2}$ Department of Surgery and Radiology, \\ ${ }^{3}$ Department of Animal Breeding and Genetics, ${ }^{4}$ Department of Veterinary Clinical Medicine, \\ College of Veterinary Science \& A.H, OUAT, Bhubaneswar-751003, Odisha, India
}

*Corresponding author

\section{A B S T R A C T}

\section{Keywords}

Gastro-enteritis,

Hemoglobin,

Glucose, Albumin

Article Info

Accepted:

26 May 2020

Available Online:

10 June 2020
The current study aimed to estimate the haemato-biochemical profile of dogs affected with hemorrhagic gastroenteritis. The diagnostic confirmation was based on history, clinical sign and symptoms. We hypothesized that $\mathrm{Hb}$, lymphocyte, glucose and albumin were significantly $(\mathrm{P}<0.5)$ lower while that of PCV, TLC, neutrophil, monocytes and cholesterol were significantly higher in affected dogs. Furthermore the eosinophil and globulin values were increased and those of TEC and total protein were decreased in affected dogs but were statistically nonsignificant.

\section{Introduction}

Hemorrhagic gastro enteritis (HGE) also known as acute hemorrhagic diarrhea syndrome, acute disorders of dog typically affects young to middle age, small breed dogs and its clinical course usually includes a peracute onset of clinical signs that can progress rapidly to death without appropriate therapy (Triolo et al., 2003; Guilford et al., 1996). The gastro intestinal tract is a "shock organ" in the dog and lack of proper perfusion to the GI tract can lead to worsening GI inflammation, bacterial translocation, sepsis and disseminated intra vascular coagulation (Hackett, 2002). HGE is mainly characterized by acute onset of bloody diarrhea along with an elevated packed cell volume (PCV) (Triolo et al., 2003).

Clinical signs of vomiting and depression, progressing to explosive, bloody diarrhea and anorexia are classic and the diarrhea often is described as having the appearance of raspberry jam (Triolo et al., 2003). There are different causative agents responsible for 
HGE in dogs including viruses as corona virus (Toma and Moraillon, 1980), rota virus (Barrios et al., 1989) and parvo virus (Hoskins, 1997). Bacteria as; salmonella spp. (Chaudhary et al., 1985), Escerichia coli (Prada et al., 1991) and Clostridium spp. (Turk et al., 1992). Endoparasites as; Dipyllidium caninum and Ancyclostoma caninum (Kumar et al., 2001). Food allergy (Kumar et al., 2003) and irritant drugs (Waters et al., 1992) are also responsible for HGE in dogs.

Dogs are useful and important domestic animals and pets. Hence they must be well protected from various infectious diseases (Richa et al., 2018). The diseases can be detected by examination of skin, blood analysis, urinary test, x-rays etc. Out of the above mentioned tests blood is one of the important body fluids for assessment of health status of animals. The evaluation of blood parameters is conducted in diagnosis of many diseases (Ariyibi et al., 2002).

Haematological and biochemical parameters are not sufficiently specific to identify the cause of enteric disease, but they can provide important information to establish a list of differential diagnoses, to assess the patient's response to treatment and to suggest a prognosis (Goddard et al., 2008; Kalli et al., 2010). Thus the present study was undertaken to analyze the haematological and biochemical findings in dogs diagnosed with hemorrhagic gastroenteritis.

\section{Materials and Methods}

The present study was carried out in Teaching veterinary clinical complex of college of Veterinary Science \& A.H, OUAT, Bhubaneswar during the period of May August, 2017. Animals were divided in to two groups as Group-A (Healthy, $\mathrm{N}=10$ ) and Group-B (HE affected, N=20). Diagnostic evaluation of hemorrhagic gastroenteritis was based on history, clinical sign and symptoms which include haemorrhagic diarrhea, vomition, painful abdomen, anemia, anorexia, dullness, fever etc. However dogs brought to TVCC for routine check-up and having normal physiological parameters were considered as healthy. This study complies with the guidelines laid down by national and institutional guidelines concerning experiments performed on client owned animals. During collection of blood samples from dogs attention had been paid to minimize pain and all the samples collection were carried out with a high standard of care. $2 \mathrm{ml}$ of blood was collected from the radial vein in the EDTA vials for haematological study. $5 \mathrm{ml}$ of blood was collected without adding any anticoagulants in clean centrifuge tube for serum separation, clear non hemolysed supernatant serum was harvested for biochemical studies.

Haematological parameters like hemoglobin $(\mathrm{Hb})$, packed cell volume (PCV), Total erythrocyte count (TEC), Total leucocyte count (TLC) and differential leucocyte count (DLC) were estimated as per standard laboratory procedures described by Young. Serum biochemical parameters like glucose, cholesterol, Total protein, albumin and globulin were estimated as per the instruction given in commercial kits (Coral clinical system) using clinical analyzer (Systronic635).

\section{Statistical analysis}

All the parameters for each test sample were subjected to statistical analysis. Then they were analyzed by Duncan method (One- wayANOVA) and the significance (P- value) was recorded at $5 \%$ level. The complete statistical analyses were done with the help of Statistical Package for Social Scientist (SPSS) Version 22, Windows 10.0. 


\section{Results and Discussion}

The mean values of haemato-biochemical parameters of Group-A and Group-B were depicted in Table 1. In the present study hemogram revealed Group-B (HGE) have significantly $(\mathrm{P}<0.05)$ elevated level of $\mathrm{PCV}$ $\% \quad(42.10 \pm 1.35), \quad$ TLC $\quad(15.23 \pm 1.03)$, neutrophil\% $(79.43 \pm 1.96)$ and monocytes \% (6.02 \pm 0.21$)$ when compared to PCV \% (39.77 \pm 1.92$), \quad$ TLC (12.54 \pm 1.88), neutrophil\% (67.32 \pm 2.62$)$ and monocytes\% $(3.86 \pm 0.64)$ values of Group-A (Healthy).

Simultaneously significant reduced $(\mathrm{P}<0.05)$ level of $\mathrm{Hb} \mathrm{g} / \mathrm{dl} \quad(9.36 \pm 0.74)$ and lymphocytes\% (18.29 1.72$)$ were observed in Group-B (HGE) as that of Group-A $(13.18 \pm 1.13$ and 27.80 \pm 1.30$)$. Decreased levels of TEC $(6.22 \pm 0.55)$ was observed in Group-B (HGE) when compared to TEC $(6.83 \pm 0.31)$ value of Group-A. Biochemical pictures depicted about significant $(\mathrm{P}<0.5)$ change in glucose $\mathrm{mg} / \mathrm{dl}$ (Group-A105.83 \pm 3.52 ; Group-B-91.28 \pm 4.21 ), albumin $\mathrm{g} / \mathrm{dl}$ (Group-A - $4.48 \pm 0.26$; Group-B $2.82 \pm 0.47$ ) and Cholesterol mg/dl (Group-A81.35 \pm 1.30 ; Group-B-103.16 \pm 3.63 ). However other biochemical parameters such as Total protein (Group-A-7.21 \pm 0.23 ; Group-B$6.39 \pm 0.31$ ) and globulin (Group-A2.75 \pm 0.34 ; Group-B-3.57 \pm 0.26 ) did not show any significant alterations.

Decreased value of $\mathrm{Hb}$ and TEC in group-B might be due to anemia in hemorrhagic gastroenteritis (Mohan et al., 1994), dehydration (Rai et al., 1994), mechanical obstruction and massive sloughing of epithelial cells (Mallela et al., 2006) and damage of capillaries of villi in the intestine leading to hemorrhages ( Sulthana et al., 2015). These observations were also noticed by (Lee et al., 2012 and Ali et al., 2014).

Table.1 Haematological and Biochemical results in gastro-enteritis

\begin{tabular}{|c|c|c|c|}
\hline SL.NO & $\begin{array}{l}\text { Haemato-Biochemical } \\
\text { Parameters }\end{array}$ & $\begin{array}{c}\text { Group-A (Healthy) } \\
(\mathbf{N}=\mathbf{1 0})\end{array}$ & $\begin{array}{c}\text { Group-B (HGE) } \\
(\mathbf{N}=20)\end{array}$ \\
\hline 1. & PCV \% & $39.77^{\mathrm{a}} \pm 1.92$ & $42.10^{\mathrm{b}} \pm 1.35$ \\
\hline 2. & $\mathrm{Hb}$ g/dl & $13.18^{\mathrm{a}} \pm 1.13$ & $9.36^{\mathrm{b}} \pm 0.74$ \\
\hline 3. & $\mathrm{TLC} 10^{3} / \mu \mathrm{l}$ & $12.54^{\mathrm{a}} \pm 1.88$ & $15.23^{b} \pm 1.03$ \\
\hline 4. & $\mathrm{TEC} 10^{6} / \mu 1$ & $6.83 \pm 0.31$ & $6.22 \pm 0.55$ \\
\hline 5. & Neutrophils $\%$ & $67.32^{\mathrm{a}} \pm 2.62$ & $79.43^{b} \pm 1.96$ \\
\hline 6. & Lymphocytes\% & $27.80^{\mathrm{a}} \pm 1.30$ & $18.29^{b} \pm 1.72$ \\
\hline 7. & Monocytes\% & $3.86^{\mathrm{a}} \pm 0.64$ & $6.02^{\mathrm{b}} \pm 0.21$ \\
\hline 8. & Eosinophils\% & $1.02 \pm 0.57$ & $1.26 \pm 0.32$ \\
\hline 9. & Glucose $\mathrm{mg} / \mathrm{dl}$ & $105.83^{\mathrm{a}} \pm 3.52$ & $91.28^{\mathrm{b}} \pm 4.21$ \\
\hline 10. & Cholesterol mg/dl & $81.35^{\mathrm{a}} \pm 1.30$ & $103.16^{\mathrm{b}} \pm 3.63$ \\
\hline 11. & Total protein $\mathrm{g} / \mathrm{dl}$ & $7.21 \pm 0.23$ & $6.39 \pm 0.31$ \\
\hline 12. & Albumin g/dl & $4.48^{\mathrm{a}} \pm 0.26$ & $2.82^{\mathrm{b}} \pm 0.47$ \\
\hline 13. & Globulin g/dl & $2.75 \pm 0.34$ & $3.57 \pm 0.26$ \\
\hline
\end{tabular}

Superscript bearing different letters $(\mathrm{a}, \mathrm{b})$ in the same row differ significantly $(\mathrm{P}<0.05)$

In the present study Group-B dogs were having elevated level of PCV which was in accordance with finding of Biswas et al., (2005) who reported that increased PCV secondary to fluid loss is the most consistent finding in acute hemorrhagic gastroenteritis. Leucocytosis might be due to primary or secondary bacterial infection, acute 
intravascular haemolysis with the damage to the tissues of liver and other organs or from secondary resurgence of bone marrow leading to increased production of cells with a shift of the cells from the marginal pool to the circulating pool (Sharmai et al., 2008).

Neutrophilia and lymphopenia could be due to general reaction of immune system to bacterial infection and inflammatory process in gastro intestinal tract (Berghoff et al., 2011).

Hypoglycemia in Group-B (HGE) might be due to inappetance (Shinde et al., 2000) complemented by mal absorption from intestine (Coles, 1986). Hypoproteinemia might be happened due to leakage of serum protein through damaged capillaries of villi of intestine and also due to less absorption through damaged villi (Kumar et al., 2017).

Significant decrease in albumin and non significant increase in globulin might be due to marked decline in diet intake, malabsorption and protein losing enteropathy (Craven et al., 2011; Dossin et al., 2011 \& Allenspach et al., 2007).

\section{Acknowledgements}

The authors would like to thanks incharge, TVCC, Department of Veterinary Physiology and Biochemistry, C.V.Sc. and A.H., O.U.A.T. for providing necessary facilities to conduct the present study.

\section{References}

Ali, B.H., Al Za'abi, M., Ramkumar, A., Yasin, J. and Nemmar, A. 2014. Anemia in adenineinduced chronic renal failure and the influence of treatment with gun acacia thereon. Physiological Research. 63(3): 351-8

Allenspach, K., Wieland, B. and Grone, A. 2007. Chronic enteropathies in dogs. Evaluation of risk factors for negative outcome.
Journal of Veterinary Internal Medicine. 21(4): 700-708

Ariyibi, A.A., Oyeyemi, M.O. and Ajadi, R.A. 2002. A comparative study of some hematology and biochemical parameters of clinically healthy Alsatian and local dogs. African Journal of Biomedical Research. 5: 145-147

Arora R., Tyagi, A., Shekhar, S., Rajora, V.S. and Arora, N. 2018. Haemato-biochemical alterations in gastroenteritis affected dogs. Journal of Entomology and Zoology studies. 6 (5): 972-974

Barrios, M., Luya, M.L., Reyna, A., Lorenzo, M. and Action, L. 1989. Isolation of parvovirus from a dog with haemorrhagic gastroenteritis in cuba. Revista-Cubana-LeCienciasVeterinarians. 20: 297-304

Berghoff, N. and Steiner, J. M. 2011. Laboratory tests for the diagnosis and management of chronic canine and feline enteropathies. Veterinary Clinics of Small Animal. 41: 311-328

Biswas, S., Chakravorty, D. and Pradhan, N. R. 2005. Clinical and haemato-biochemical changes in parvovirus infection in dogs. Indian Journal of Veterinary Medicine. 25(1): 16-18

Burrows, E.F. (1977). Canine haemorrhagic gastroenteritis. J. Am. Anim. Hosp. Assoc. 13: $451-458$

Chaudhary, S.P., Kalimuddin, M., Prasad, G., Verma, B.B. and Narayan, K.G. 1985. Observation on normal and experimental salmonellosis in dogs. J Dis Res 3: 149-153

Coles, E. H. 1986. Veterinary Clinical Pathology. W.B Saunders Company, Philadelphia.

Craven, M., Caroline, S. M. and Kenneth, W. S. 2011. Granulomatous Colitis of Boxer dogs. Veterinary Clinics of Small Animal. 41: 433-445

Dossin, O. and Lavour, R. 2011. Protein-losing enteropathies in dogs. Veterinary Clinics of Small Animal. 41: 399-418

Goddard, A., Leisewitz, A.L., Christopher, M.M., Duncan, N.M. and Becker, P.J. 2008. Prognostic usefulness of blood leukocyte changes in canine parvoviral enteritis. $\mathrm{J}$ Vet Intern Med. 22: 309-316

Grigonis, A., Macijauskas, V., Zamokas, G. 2002. Examination of liver functions in dogs with 
parvovirus enteritis. Veterinarian-irZootechnika.; 17: 23-28

Hoskins, L.D. 1997. Update on canine parvoviral enteritis. Vet Med Ang: 694-709

Kalli, I., Leontides, L.S., Mylonakis, M.E., Adamama-Moraitou, K., Rallis, T. Koutinas, A. 2010. Factors affecting the occurrence, duration of hospitalization and final outcome in canine parvovirus infection. Res Vet Sci.; 89: 174-178

Kumar, S., Reddy, K.M.P. and Chaudhary, P.E. 2001. A rare case of mixed infestation of $D$. caninum and A. caninum in Doberman dogs and its therapy. Vet Pract 2: 57-58

Kumar, R., Kumar, A. and Sharma, R, 2003. Therapeutic management of food allergy in canines. J Canine Develop Res 3: 97-100

Kumar, A. and Kumar, R. 2017. Clinicohematobiochemical changes in parvo viral infection in dog. International Journal of Science, Environment and Technology. 6(5): $2837-2841$

Lee, S.Y., Lee, Y.S., Choi, H.M., Ko, Y.S., Lee, H.Y. and Jo, S.K. 2012. Distinct pathophysiologic mechanisms of septic acute kidney injury: role of immune suppression and renal tubular cell apoptosis in murine model of septic acute kidney injury. Critical Care Medicine. 40: 29973006

Macartney, L., McCandish, L. A.P., Thompson, H. and Comwell, H.LE. 1984. Canine parvovirus enteritis: Clinical, hematological and pathological features of experimental infection. Vet. Rec. 115: 201-210.

Mallela, M.K., Bhutia, Y.D., Suryanarayan, C., Rajni, B. Reddy, M.C.S. 2006. Efficacy of conservative therapy in managing chronic renal failure in dogs. Indian Veterinary Journal. 26: 82-89

Mohan, R., Nauriyal, D.C. and Singh, K.B. 1994. Electrocardiographic alterations in canine parvoviral infection. Indian Veterinary
Journal. 71: 484-488

Prada, L., Baljer, G., Steinruck, H., Zimmermann, S., Stephanm, R., Bevtin-L-De and Rycki, L. 1991. Characteristics of alpha hemolytic strains of Escherichia coli isolated from dogs with gastroenteritis. Vet Microbiol 29: 59-73

Sharmai, R., Kumar, A., Goel, P. and Kumar, R. 2008. Clinical haematology in canine haemorrhagic gastroenteritis. Haryana Vet. 47: $35-38$

Rai, A, Nauriyal, D.C. and Mohan, R. 1994. Anoteonhaematological observations in canine parvoviral gastroenteritis. Indian Veterinary Journal. 13: 99

Shinde, S. S., Rajguru, D. N., Anantwar, L. G., Mohd, S. and Ambore, B. N. 2000. Clinicopathology and therapeutic management of canine gastroenteritis. The blue cross book 15(1): 26-29

Sulthana, C.M.J. 2015. Clinico-Pathological Findings in Dogs Affected with Canine Parvo Virus (CPV) Infections, Intas Polivet. 16(II): 443-444

Toma B and Moraillon A, 1980. Infection of the dog by a coronavirus antigenically related to porcine transmissible gastroenteritis virus. Recueil de medecine veterinaire 156 : 464- 470.

Turk L, FalesN, Miller M, Paer L, Fesches I and Gasser H, 1992. Enteric Clostridium perfringens infections associated with parvoviral enteritis in dogs. J Am Vet Med Assoc 200: 991-994

Waters EB, Hawkin EC and Knapp DW, 1992. Acute thallium toxicosis in a dog. J Am Vet Med Assoc 21: 883-885.

Young KM. Eosinophils. In: Feldman BF, Zinkl JG, Jain NC, eds. Schalm's Veterinary Hematology, 5th ed. Philadelphia, PA: Lippincott Williams \&Wilkins, 2000, 297307.

\section{How to cite this article:}

Maharathi, S. P., N. Dalai, S. R. Mishra, S. Mohapatra, A. P. K. Mahapatra, A. K. Kundu, I. Nath, S. Dash and Jena, G. R. 2020. Comparative Haematobiochemical Analysis between Haemorrhagic Enteritis affected Dogs with Normal Ones. Int.J.Curr.Microbiol.App.Sci. 9(06): 3695-3699. doi: https://doi.org/10.20546/ijcmas.2020.906.436 